\title{
Value Chain Analysis of Frankincense in Hammer and Benna-Tsemay Districts of the South Omo Zone, South Western Ethiopia
}

\author{
Asmera Adicha*1, Asmelash Tesfaye ${ }^{2}$, Shimelis Tesema ${ }^{2}$ and Demis Segaw \\ ${ }^{1}$ Department of Socioeconomics Researchers, Southern Agricultural Research Institute, Ethiopia \\ ${ }^{2}$ Department of Natural Resource Researchers, Southern Agricultural Research Institute, Ethiopia
}

Submission: December 05, 2017; Published: December 14, 2017

*Corresponding author: Asmera Adicha, Department of Socioeconomics Researchers, Southern Agricultural Research Institute, Jinka Agricultural Research Center, Ethiopia, Email: asmera05@gmail.com

\begin{abstract}
A study was conducted in Hamer and Benna-Tsemay districts of the South Omo zone of Ethiopia, with the objectives of identifying and mapping the market chain and its functions, providing the picture of supply and use patterns, identifying and suggesting possible intervention of value additive techniques, identifying potential opportunities and constraints in the production, processing and marketing of Frankincense. Twostage sampling strategy used to select Frankincense collectors for the study the producers/collectors and traders within society as well nearby marketing systems were studied through group discussion, personal observation, and using a structured questionnaire where each household was taken as a unit of analysis (45 households from Hammer, 15 from Benna-Tsemay). Simple descriptive statistical tools were used for the analysis. Observation among value chain were summarized using Strength, Weakness, Opportunity and Treat (SWOT) analysis and software called Statistical Package for Social Science (SPSS) were also used for the analysis. Survey results show that almost all of the respondents confirmed that the incense products potentially collected from the natural forest found far away from their villages. Currently the marketing of Frankincense both at Hammer and Benatsemay Woreda of south Omo zone in general is not well developed and there is no established market in place. To advance the value chain the of Frankincense and sustainably contribute to the income of pastoral communities formation of collector groups, associations or cooperatives is needed to foster cooperation and coordination of the collection and marketing of Frankincense.
\end{abstract}

Keywords: Frankincense; Marketing; Value Added; Value Chain

Abbreviations: SWOT: Strength Weakness Opportunity Treat; SPSS: software called Statistical Package for Social Science; NTFP: Non-Timber Forest Products; PNRM: Participatory Natural Resource Mapping

\section{Introduction}

In rural Ethiopia, a majority of the households make use of nontimber forest products (NTFPs) for different purposes, ranging from food, feed, energy, and medicine to income generation and cultural practices [1,2]. As provided by among the range of NTFPs, gums and resins are important trade commodities with a potential for spurring economic and social developments both at rural and urban areas in Ethiopia [3-5]. Commercial gums and resins are produced in rural (remote) areas, traded in urban centers, and consumed by western countries and, hence, touch wide ranges of human lives and cross-sections [6-8]. However, recent studies revealed poor linkage of rural producers to the market niches and, hence, lack of proper producers' marketing system [5]. Sound development of the value chain of Frankincense will, thus, have a massive impact on the larger population, especially the vulnerable rural poor dependent upon natural resources in the country $[9,10]$. Moreover, in the south Omo zone, value chain of the Frankincense starting from inception to consumption among major actors (producers//collectors, processors, traders, middlemen, and commission agents and consumers) are not yet studied and documented. Thus, the value chain analysis of Frankincense is carried out with the following objectives:

a) To identify and map the market chain of Frankincense and its functions

b) To provide the picture of supply and use patterns of Frankincense

c) To identify and suggest possible intervention of value additive techniques of Frankincense

d) To identify potential opportunities and constraints in the production, processing and marketing of Frankincense

\section{Methods}

\section{Description of the study area}

The study was conducted in Hamer and Benna-Tsemay districts of south omo zone found in the Southern Nations, Nationalities, and People's Regional State of Ethiopia. The two districts have a total land area of $9,496 \mathrm{~km}^{2}$ (Hamer $=5,742 \mathrm{~km}^{2}$ and Benna-Tsemay $=3,754 \mathrm{Km}^{2}$ ). The districts are located $4^{\circ}$ 
$27^{\prime}-5^{\circ}$ 39' north and 35 $23^{\prime}-37^{\circ}$ 49' east, bordering Kenya to south; Bako gazer district to the north; Borana zone and Konso district to the east, and Kuraze and Selamago districts to the west. The study districts, Benna-Tsemay (Key Afer) and Hamer (Dimeka), are located at about 739 and $839 \mathrm{~km}$ from the capital city Addis Ababa, respectively. Furthermore, Key Afer and Dimeka are located 402 and $602 \mathrm{~km}$ from Hawassa, respectively [11]. The study area is characterized by semi arid and arid climatic conditions, with mean annual rainfall increasing from the extreme south lower part, with some $350 \mathrm{~mm}$, to the upper part where it ranges to $838 \mathrm{~mm}$. The rainfall is bimodal, with the long rain season from March to June and the small rain. Forest composition of districts are a mixture of Acacia, Boswellia and Commiphora woody species and short grasses type with varying density of woody vegetation (woreda classification). The arid and semiarid zones are the preferred sites for Boswellia and Commiphora species (in altitude less than 1250 m.a.s.l). Acacia nilotica is the dominant woody plant in altitude ranging from 1,250 m.a.s.l to 1,600 m.a.s.l. Agro-mountain broad leaf wood plants with floristic elements of the Ethiopia highland is the typical vegetation in altitude above1, 600 m.a.s.l. [11]. The pastoralists in the study districts raise cattle, goats, sheep and chicken as well they harvest honey from traditional hives and wild honey from the inside holes of trees and between rocks.

\section{Data source and sampling techniques}

This study used primary and secondary data sources. The secondary sources included Agriculture and rural development offices and development agents. primary data collected through focus group discussions with development agents, elders' women, young's, men and kebele administrative: key informant interviews with key person in the area: field observations and over viewing marketing system (Figure 1).

Field observations: They collect the exudates (ooze) from a standing tree by climbing on it to nearest branches by their own bare hands and sometimes they use sharp local materials such as knife and stone. Children and elders are the main collectors while chasing after group of goats and cattle who has been responsible for brought into the natural pasture and permanent water sources (Figure 2).

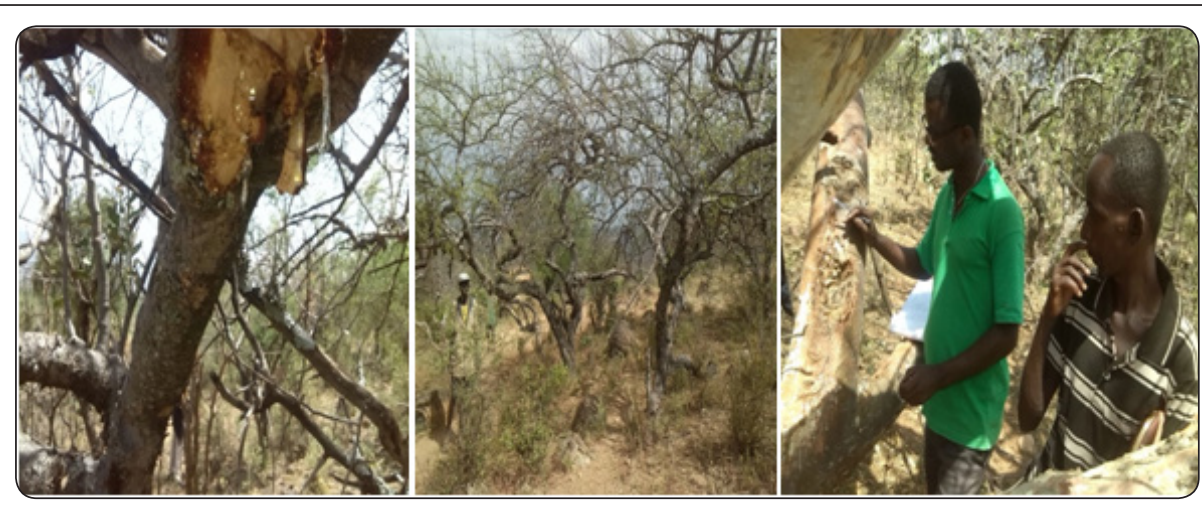

Figure 1: Wound trees ooze the incense and tapping technique.

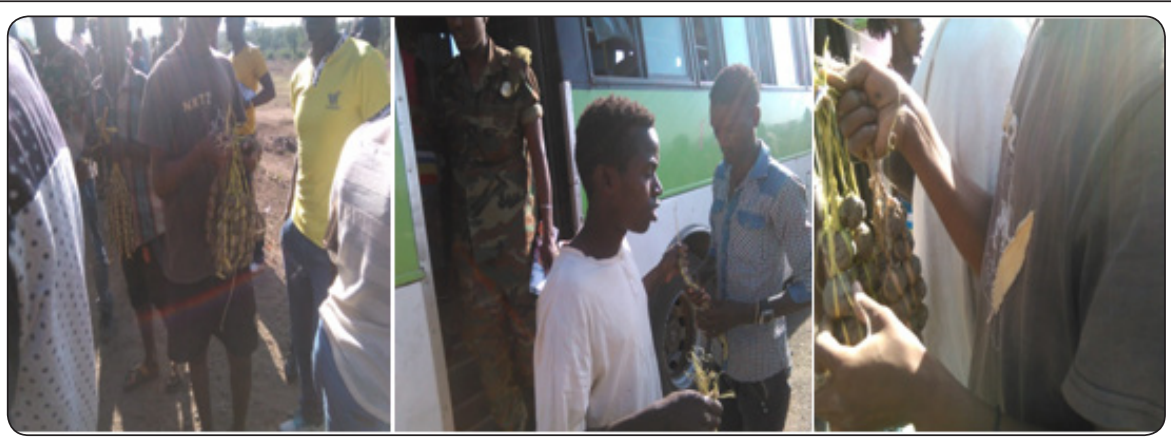

Figure 2: Marketing system.

Passengers purchase at the road side: Two-stage sampling strategy used to select Frankincense collectors for the study: Stage 1: purposive sampling to select the districts and kebeles. Stage 2: random sampling to select individual households for survey. Three pastoralist kebeles from Hammer district (Marsha kelema, bita gelefa and gembela) and two pastoralist kebeles from Benatsemay district (luka and ufo) were selected. And a structured and pretested questionnaire was administered to sixty(60) households in the Hammer and Benatsemay Woreda. The questionnaire was designed in such a way that it enables to collect data on the demographic and socio-economic characteristics of households, potential opportunities and constraints in production ,production and use pattern , picture of supply ,market chain and marketing of incense in the study area. 


\section{Data analysis}

Simple descriptive statistical tools were used for the analysis. Observation among value chain were summarized using Strength, Weakness, Opportunity and Treat (SWOT) analysis and software called Statistical Package for Social Science (SPSS) were also used the analysis.

\section{Results and Discussion}

This chapter deals with the analysis of the survey data and interpretation of the analytic finding.

\section{Demographic and Socio-economic Characteristics}

A majority of the respondent households are between 20 and 55 years old and male-headed (Table 1). In rural Ethiopia, due to cultural influence, it is common to find few female-headed households. Illiteracy is prevalent and only $20 \%$ of the respondent households completed primary school. In contrast to government reports that indicate significant improvement in educational access for children and youth, none of the family heads below 20 years of age had completed even primary school [12]. Almost $50 \%$ of the family sizes of the respondents are above 5 . This shows that family planning in the area is poor. The major occupation the respondents in the area is livestock and crop production, Frankincense collection, honey/bee farming.

Table 1: Demographic characteristics of household respondents involved in gums and resins collection in Hammer and Benatsemay of south Omo Zone $(\mathrm{N}=60)$.

\begin{tabular}{|c|c|c|c|c|c|c|c|c|c|c|}
\hline \multirow{2}{*}{$\begin{array}{c}\text { Age of } \\
\text { household } \\
\text { head }\end{array}$} & \multicolumn{3}{|c|}{ Gender } & \multicolumn{3}{|c|}{ Level of education } & \multicolumn{4}{|c|}{ Family size } \\
\hline & Male & Female & Total & illiterate & primary & Total & $\leq 5$ & $5-8$ & $\geq 9$ & total \\
\hline$<20$ & 2 & 0 & 2 & 0 & 2 & 2 & 2 & 0 & 0 & 2 \\
\hline 20-35 & 20 & 0 & 20 & 11 & 9 & 20 & 11 & 8 & 1 & 20 \\
\hline $36-45$ & 12 & 1 & 13 & 10 & 3 & 13 & 6 & 6 & 1 & 13 \\
\hline $46-55$ & 12 & 3 & 15 & 15 & 0 & 15 & 5 & 8 & 2 & 15 \\
\hline$>55$ & 9 & 1 & 10 & 10 & 0 & 10 & 2 & 7 & 1 & 10 \\
\hline Total & 55 & 5 & 60 & 46 & 14 & 60 & 26 & 29 & 5 & 60 \\
\hline
\end{tabular}

\section{Production and use pattern of Frankincense}

Survey results show that almost all of the respondents confirmed that the incense products potentially collected from the natural forest found far away from their villages. As revealed by Woreda agricultural development office and development agents the annual production potential of Frankincense from natural forest at both Hammer and Benatsemay district were on average $500-600 \mathrm{~kg} /$ year and $720-840 \mathrm{~kg} /$ year respectively. Most of the studied households are engaging in Frankincense activities, i.e. either in tapping/collection, marketing, or both activities to generate cash income. Income generated from sale of Frankincense helps in meeting household needs, purchasing food and supporting livestock keeping activities. Annual income from Frankincense sales in the agro pastoralist kebeles of Luka, Ufo, Marsha Kelema, Bita Gelefa and Gembela mostly ranged from 3,000 to 9,000 birr (Table 2). The average cash income from Frankincense sales among the 60 surveyed households was about 5312.7 birr/ year during the survey period. Total annual income from Frankincense sales for all surveyed households is: 5312.7 birr* 60 households $=318,762$ birr.

Table 2: Pastoralists' annual income from sale of gum and incense, by kebele.

\begin{tabular}{|c|c|c|c|c|c|c|c|c|c|c|}
\hline \multirow{3}{*}{$\begin{array}{l}\text { Income } \\
\text { range } \\
\text { (birr) }\end{array}$} & \multicolumn{4}{|c|}{ Benatsemay } & \multicolumn{6}{|c|}{ Hammer } \\
\hline & \multicolumn{2}{|c|}{ Luka $(\mathrm{N}=10)$} & \multicolumn{2}{|c|}{ Ufo $(\mathrm{N}=5)$} & \multicolumn{2}{|c|}{ Marsha kelema $(\mathrm{N}=15)$} & \multicolumn{2}{|c|}{ Bita gelefa $(\mathrm{N}=16)$} & \multicolumn{2}{|c|}{ Gembela $(N=14)$} \\
\hline & $\mathbf{N}$ & $\%$ & $\mathbf{N}$ & $\%$ & $\mathbf{N}$ & $\%$ & $\mathbf{N}$ & $\%$ & $\mathbf{N}$ & $\%$ \\
\hline $3000-4000$ & 2 & 20 & 1 & 20 & 3 & 20 & 2 & 12.5 & 3 & 21.43 \\
\hline $4001-5000$ & 1 & 10 & 2 & 40 & 5 & 33.33 & 2 & 12.5 & 4 & 28.57 \\
\hline $5001-6000$ & 5 & 50 & 1 & 20 & 3 & 20 & 6 & 37.5 & 3 & 21.43 \\
\hline $6001-7000$ & 1 & 10 & 1 & 20 & 2 & 13.33 & 4 & 25 & 3 & 21.43 \\
\hline 7001-8000 & 1 & 10 & & & 1 & 6.67 & 1 & 6.25 & 1 & 7.14 \\
\hline $8001-9000$ & & & & & 1 & 6.67 & 1 & 6.25 & & \\
\hline
\end{tabular}

Source: own survey (2005/6 E.C)

\section{Market chain of Frankincense}

Currently the marketing in Frankincense both Hammer and Benatsemay Woreda of south Omo zone in general is not well developed and there is no established market in place. Buying and selling is done at many levels ranging from the collection point up to marketing centres in small towns (Turmi-for Hammers; Luka, Woito and keyafer for Benatsemays). As respondents stated that still now they do not have permanent customers to sell the incense. But mostly passengers and town dwellers purchase from small town marketing centre and at the road side. Also they revealed 
that it takes a long time to market Frankincense and collectors lack sound market information to guide them on opportunities, trends and price mechanisms. The price of the Frankincense increases as the commodity heads to the end of the value chain. The number of traders buying Frankincense are few, mostly based in marketing centers that buy at collection points or small centers and in return sell to them. However, there is an emerging trend where traders are going around and buying incense directly from collectors.

As it is well understood from the group discussion respondents confirmed that during different occasion of time the incense production and marketing cooperatives have been formulated with ultimate support and initiatives of two different NGO's (Farm
Africa-Hammer and Benatsemay, and AFD-Hammer). Moreover, different trainings concerning tapping and handling of incense products have been organized by pastoral and agro-pastoral development office of the two discrete wore das. However, none of the cooperatives have been functional due to lack of continuous follow up and support. Collectors are paid 12-14birr per kg for black and 40-50birr per kg white incense by both middlemen and local traders. Middlemen and local traders mostly sell at 16-20birr per kg black and 50-60birr per kg white incense to town dwellers and passengers. However there is no trader who transports the Frankincense to exporters. According to collectors, in recent years the price of Frankincense has improved (Tables $3 \& 4$ ).

Table 3: Shows price and quantity relationships of incense product in local market (2001-2006 E.C).

\begin{tabular}{|c|c|c|c|c|}
\hline \multirow{2}{*}{ Years (E.C) } & \multicolumn{2}{|c|}{ White } & \multicolumn{2}{c|}{ Black } \\
\cline { 2 - 5 } & Quantity (kg) & Unit price (ETB) & Quantity (kg) & 20 \\
\hline 2006 & 1 & 50 & 1 & 20 \\
\hline 2005 & 1 & 44 & 1 & 15 \\
\hline 2004 & 1 & 35 & 1 & 10 \\
\hline 2003 & 1 & 30 & 1 & 5 \\
\hline 2002 & 1 & 20 & Exchange of goods for other goods \\
\hline 2001 & \multicolumn{2}{|c|}{ Bartering } \\
\hline
\end{tabular}

Source: Survey data (2005/2006).

Table 4: Swot analysis.

\begin{tabular}{|c|c|}
\hline Swot analysis & Description \\
\hline Strength & starting production i.e. early no or low production \\
\hline Weakness & $\begin{array}{l}\text { Lack of tapping experience, Poor handling and storing practices, Lack of value additive activities, Non functionality of } \\
\text { cooperatives due to lack of continues follow-ups and support. }\end{array}$ \\
\hline Opportunities & $\begin{array}{c}\text { Initiative from governmental and nongovernmental organization to organize trainings (on processing \& marketing) for } \\
\text { different cooperatives so as to provide quality product, More production if there were organized team or cooperatives with } \\
\text { legal binding of rules and regulation. }\end{array}$ \\
\hline Treats & $\begin{array}{c}\text { Deforestation is the most problem that has been hampering the sustainable production of gum by non stopping } \\
\text { encroachment of tree species for purpose of farm land expansion and farm implements, Price deflation and decreasing } \\
\text { demand for the product due to poor Infrastructure and market access. Decreasing number of potential gum bearing tree } \\
\text { species. }\end{array}$ \\
\hline
\end{tabular}

From the above table in the years (2001-2003) it was so cheap. But recently, its value increased. As quantity increase, the prices also increase in consecutive years (2004-2006) of production and this shows that trends in production increase due to increase in price. There are a number of reasons that trigger the demand and price of incense products. According to respondents, the most reason is the season of production. Dry season is the potential period of incense production and consequently high production of incense has been collected by the community. However, during this period the price of incense has been dropped due to equilibrium of the market and the reverse is true for rainy season (Figure 3). Hence, the major steps in the collection and marketing value chain of Frankincense can be tapping (collection) -- Processing -- local market/passengers. As the collected Frankincense move through this chain in both districts of the study area.

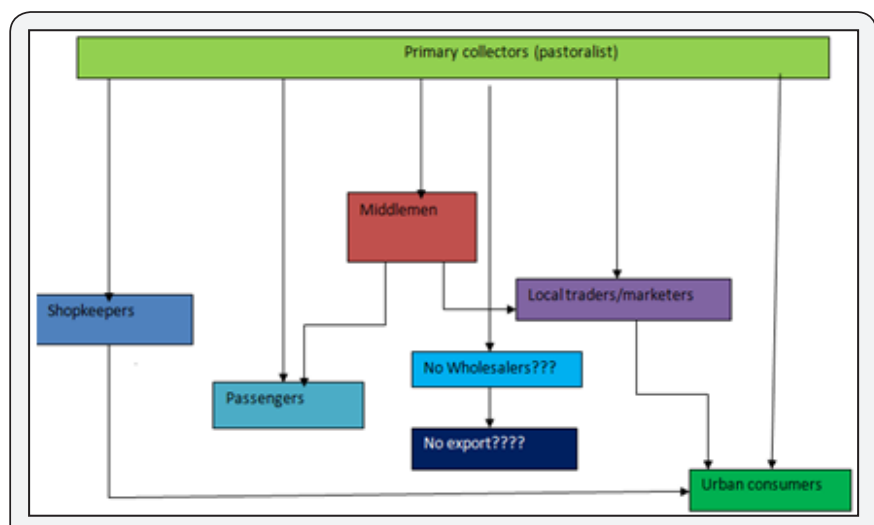

Figure 3: Value chain map of the key actors involved in Frankincense sells. 


\section{Value adding system}

The ways of Frankincense collection/tapping systems at the study areas are wounding the tree stem and expanding the wound periodically and collect from natural oozing of trees. As shown in Figure 1 due to lack of appropriate tapping skill it causes damage to incense bearing species. Studies advocate existing tapping techniques are either ineffective (e.g., damage the tree) or improper for the various Frankincense bearing species. Until recently, there is no suitable tapping technique to tap gum- and resin-bearing species except $B$ papyrifera. Hence, searching for best techniques to optimize harvesting of quality product from different species, product processing, and value addition to the final product (e.g., grading based on chemical composition and oil extraction) are critical [13].

\section{Potentials and constraints in production and marketing}

\section{Potentials}

a) Availability of resource to engage in production and gain benefits from the resource

b) High demand for incense in the local market

\section{Constraints}

a) Lack of experience and poor working culture of the local people to harvest incense

b) Lack of warehouse and technical problems during tapping.

c) Seasonality in production and low unit price,

d) Lack of tenure by the local community resulting in degradation of incense trees,

e) Lack of experience in establishing incense plantation,

f) high temperature during collection seasons and distance,

g) Lack of market information Absence of permanently established cooperatives. Tapping the scattered gum and markets is not an easy matter [14]. Local communities should be organized into functioning, but also proactive, cooperatives or unions and other means of social organizations.

\section{Conclusion}

a) Survey results show that exploitation of Frankincense is one of the complementary activities next to livestock herding undertaken by pastoralists to supplement their income. Income generated from sale of Frankincense helps in meeting household, purchasing food and supporting livestock keeping activities. Two different NGO's (Farm AfricaHammer and Benatsemay, and AFD-Hammer) formulated the incense production and marketing cooperatives with ultimate support, initiatives and given different trainings concerning tapping and handling of incense products.

b) However, none of the cooperatives have been functional due to lack of continuous follow up and support. Market structures for selling Frankincense are not well structured. c) And although households depend on collection of Frankincense, are particularly disadvantaged in the trade due to lack of market information.

d) Frankincense collectors are not equipped to do effective collection due to lack of basic skills and equipment. There is no established market chain of the Frankincense i.e. simply producer to consumer (local market, passengers).

e) No organized team or cooperatives with legal binding of rules and regulation.

\section{Recommendation}

To move ahead the value chain the of Frankincense and sustainably contribute to the income of pastoral communities, a number of interventions are required:

\section{Production}

a) Performing Participatory Natural Resource Mapping (PNRM) to identify the existing and

b) Potential incense tree.

c) Spread out the plant population through plantation;

d) Boost community awareness and introduce bylaws to protect the incense trees;

e) Build up community action plan to manage and benefit from incense plants.

\section{Marketing}

a) skilfulness building in incense tree management and harvesting;

b) Formation of collector groups, associations or cooperatives is needed to foster cooperation and coordination of the collection and marketing of incense.

c) Setting specific market regulation policy that will govern access to resources, markets, technologies, producer s value chain of Frankincense resources.

d) Establishing market chain (up to export) and linkage.

\section{References}

1. Babulo B, M Bart, N Fredu, T Eric, N Jan, et al. (2008) Household livelihood strategies and forest dependence in the highlands of Tigray, Northern Ethiopia. Agricultural Systems 98(2): 147-155.

2. Tesfaye Y, R Anders, MC Bruce, B Folke (2011) Livelihood strategies and the role of forest income in participatory-managed forests of Dodola area in the Bale highlands, southern Ethiopia. Forest Policy and Economics 13(4): 258-265.

3. Kassa H, T Berihun, F Girmay (2011) Preliminary Value Chain Analysis of Gum and Resin Marketing in Ethiopia: Issues for policy and research, Indonesia, p. 1-12.

4. Lemenih M, H Kassa (2011) Opportunities and Challenges for Sustainable Production and Marketing of Gums and Resins in Ethiopia. CIFOR, Bogor, Indonesia.

5. Worku A, D Teketay, M Lemenih, M Fetene (2011) Socio-economic importance of gum and resin resources in the dry woodlands of Borana, southern Ethiopia. Forests, Trees and Livelihoods 20(2-3): 137-155. 
6. FAO (2010) Guideline on Sustainable Forest Management in Drylands of Sub-Saharan Africa. Arid Zone Forest and Forestry Working Paper No. 1 FAO, Rome, Italy.

7. ICRAF (2009) Making Sub-Saharan Africa Forest Work for People and Nature: Policy approaches in a changing global environnent. ICRAF, Nairobi, Kenya.

8. Lemenih M, D Teketay (2003) Frankincense and myrrh Resources of Ethiopia: II. Medicinal and industrial uses. Ethiopian Journal of Science 26(2): 161-172.

9. Gemtessa K (2001) Study to Initiate Sustainable Micro-finance Service in the Somali National Regional State: Report submitted to the regional affairs sub-sector of the Prime minister's Office and the Somali Regional Government. Addis Ababa Ethiopia, Ethiopia.

10. Worku A, A Alemu, W Tadesse (2011) Overview of research achievements and gaps on dryland forests of Ethiopia: The case of gum-resins bearing resources. By (Eds.) A Worku, G Animut, H Kassa, S Sintayehu, W Tadesse, et al. In Proceedings of the National Workshop on Research and Development in Dryland Forests of Ethiopia. Forum for Environment, Addis Ababa, Ethiopia, p. 1-24.
11. Alemayehu Mulugeta, Tezera Getahun (2002) Socio-economy of pastoral Community in Bena-Tsemay and Hamer Woredas of South Omo Zone, Southern Nations and Nationalities peoples Regional State. Addis Abeba, Ethiopia.

12. MoFED (2010) Ethiopia: Millennium Development Goal Report. Addis Ababa, Ethiopia.

13. Asefa M (2011) A preliminary physicochemical study on the meaningfulness of grading in Boswellia papyrifera (Del.) Hochst (frankincense) trade. By (Eds.) A Worku, G Animut, H Kassa, S Sintayehu, W Tadesse, et al. in Proceedings of the National Workshop on Research and Development in Dry land Forests of Ethiopia. Forum for Environment, Addis Ababa, Ethiopia, p. 87-100.

14. Lemenih M, D Teketay (2004) Natural gum and resin resources: Opportunity to integrate production with conservation of biodiversity, control of desertification and adapt to climate change in the dry lands of Ethiopia. Paper Presented to the First National Workshop on Conservation of Genetic Resources of Non Timber Forest Products (NTFPs) in Ethiopia. Addis Ababa, Ethiopia.

\begin{tabular}{|l|}
\hline \multicolumn{1}{|c|}{ Your next submission with Juniper Publishers } \\
will reach you the below assets \\
- Quality Editorial service \\
- Swift Peer Review \\
- Reprints availability \\
- E-prints Service \\
- Manuscript Podcast for convenient understanding \\
- Global attainment for your research \\
- Manuscript accessibility in different formats \\
( Pdf, E-pub, Full Text, Audio) \\
- Unceasing customer service \\
Track the below URL for one-step submission \\
https://juniperpublishers.com/online-submission.php \\
\hline
\end{tabular}

